\title{
ART NOUVEAU HERITAGE AS A RESOURCE IN TOURISM - CHALLENGES AND SOLUTIONS
}

\author{
Rátz Tamara \\ Kodolányi János Egyetem, Turizmus Tanszék; tratz@kodolanyi.hu
}

DOI: 10.15170/TVT.2022.07.01.08.

\begin{abstract}
This study was carried out in the framework of the ARTNOUVEAU2 international project, and aims to analyse the role of Art Nouveau heritage in tourism. Although Art Nouveau has significant tourist potential in many European cities, the difficulties of collaboration between the cultural sector and the tourism industry create obstacles in its use as a resource in tourism development. Since highlighting Art Nouveau as a major brand component in destination marketing is a crucial step in this process, the paper first provides on overview of the Art Nouveau theme's appearance in selected European cities' tourist websites, then discusses the role of tour guides in Art Nouveau tourism and the collaboration possibilities between them and the cultural institutions representing Art Nouveau heritage. Furthermore, the paper also explores the possible contribution of Art Nouveau resources to transforming a destination into a "best place".
\end{abstract}

Keywords: Art Nouveau, resource, tour guide, destination marketing, best place

\section{SZECESSZIÓS ÖRÖKSÉG MINT TURISZTIKAI ERŐFORRÁS - KIHÍVÁSOK ÉS MEGOLDÁSOK}

\begin{abstract}
Absztrakt
A tanulmány az ARTNOUVEAU2 nemzetközi projekt keretében készült, célja a szecessziós örökség turisztikai szerepének elemzése. Bár a szecesszió számos európai városban jelentős turisztikai potenciállal rendelkezik, a kulturális szféra és a turizmus szektor közötti együttműködés nehézségei akadályozzák turisztikai erőforrásként való hasznosítását. Mivel a szecesszió jelentős márkaelemként való kiemelése kritikus lépés ebben a folyamatban, a tanulmány először áttekinti a szecesszió mint téma megjelenését kiválasztott európai városok turisztikai weboldalain, majd bemutatja az idegenvezetők szerepét a szecessziós turizmus fejlesztésében, illetve az idegenvezetők és a szecessziós örökséget képviselő kulturális intézmények közötti együttmüködési lehetőségeket. A tanulmány továbbá tárgyalja a szecessziós erőforrások hozzájárulásának lehetőségét ahhoz, hogy egy desztináció ,jó hellyé” váljon.
\end{abstract}

Kulcsszavak: szecesszió, eröforrás, idegenvezetö, desztináció marketing, jó hely 


\section{Introduction}

Art Nouveau heritage is part of the history and everyday life of the many cities in the world: particularly in Europe, but also on other continents where European architectural and artistic influences shaped urban development (LENNING 1951). This heritage is especially important in Central-Eastern-Europe where the Art Nouveau movement contributed to the region's cultural identity and may be used as a cohesive force in collaboration-based tourism development, at destination, national and international level. Since the Art Nouveau monuments typically display splendid decorations and a high level of craftsmanship, and are often rooted in inspiring personal stories of the artists and their patrons, their visual and emotional appeal can be used to present destinations with Art Nouveau heritage as "good places" (MICHALKÓ - FAZEKAS 2016) in the global tourism market, i.e. places that are recognizable, memorable, and attractive to visitors and locals alike.

The study presented in this paper was carried out in the framework of the ARTNOUVEAU2 project (2020-2022), an international initiative that embarked on responsibly and sustainably using Art Nouveau cultural heritage as a vehicle for strengthening regional cultural identity and for stimulating economic growth in the Danube region. ARTNOUVEAU2 aims to increase the level of knowledge related to Art Nouveau in residents and tourists, prompting them to respect, appreciate, protect and take better care of this heritage. Further objectives include the professionalization of promoting Art Nouveau as a cultural attraction through the active involvement of the tourism industry, thus contributing to the diversification of the region's tourist product and the improvement of its position in global tourism.

The objectives of the study discussed in the paper were twofold: to investigate how Art Nouveau heritage is featured in selected European destinations' marketing messages, and to explore the possibilities of developing a stronger cooperation between the cultural sector representing this heritage and the tourism industry, in order to optimally capitalize on Art Nouveau as a resource in tourism development.

This paper is dedicated to Professor Antal Aubert, whose long and successful scientific career is inextricably linked to the city of Pécs, home to some of the most beautiful Art Nouveau treasures in Hungary.

\section{Theoretical background}

Culture and tourism have a symbiotic relationship: while culture is a valuable asset in tourism development since it has a significant impact on destinations' attractiveness, the cultural sector is also a major beneficiary of tourism development (WTO 2001). Cultural resources offer content for tourism development, allowing destinations to differentiate themselves in an increasingly crowded and competitive marketplace, while tourism can provide the cultural sector with additional demand, new outlets for cultural institutions and products, and new partnerships (EUROPEAN COMMISSION 2017). Most destinations attribute a high value to cultural heritage on their agenda of tourism development and promotion, as culture can add to the distinctiveness of the local tourism product, and cultural institutions may benefit in terms of increased visitor numbers (UNWTO 2018). In addition, the increasing numbers of visitors does not only generate more income, but also serves to increase the profile and social relevance of cultural institutions (NETHERLANDS MUSEUMS ASSOCIATION 2011). Many destinations use the tourism-culture relationship as a way of bringing national culture, or certain elements of it, to international attention (WTO 1985). At regional and/or local level, the development of cultural attractions can help to attract large numbers of visitors to relatively unknown places, to position destinations as "best places" on tourists' mental maps, or to generate a new, more culture- or heritage-oriented demand. 
Cooperation with the cultural and creative industries, on the one hand, offers important opportunities for the tourism sector to

- revitalize and diversify existing tourism products,

- develop new tourism products and experiences,

- use creative technology to enhance the tourism experience, and

- add atmosphere and 'buzz' to places (OECD 2014, RICHARDS 2021).

On the other hand, tourism is also important for the cultural and creative sector, since it has the potential to

- valorise cultural and creative assets,

- expand the audience for cultural products and services,

- improve and transform the image of destinations,

- open up new markets, both in terms of visitation and in cultural production, and

- $\quad$ support professional networks and knowledge development (OOI 2007, OECD 2014).

These creative synergies have been exploited by many destinations in recent years, particularly in the development of new niche products in the field of cultural and heritage tourism, such as film-induced tourism, literary tourism, architectural tourism or music tourism (RÁTZ 2017). However, to develop competitive products on the base of distinctive cultural identity, it is necessary to highlight special features and to enhance the unique characteristics of a destination. In many cases, tourists connect the identity of a destination with aspects of its tangible culture, particularly its built heritage (SCERRI - EDWARDS - FOLEY 2018), and stunning architecture such as Art Nouveau may be more efficient in creating a "best place" identity.

The Art Nouveau movement emerged around 1890 and lasted until about 1914, and as a genuinely international style, had a profound impact on the decorative arts, interior design and architecture in many countries (MILLER et al. 2004). Compared with historicism and the period styles that defined late $19^{\text {th }}$ century interiors, Art Nouveau presented a refreshingly modern approach that challenged established traditions and offered thrilling new forms of expression (LENNING 1951). Throughout Europe, the movement reflected the individual character of each country where it appeared, resulting in a wide range of designations such as Art Nouveau in Belgium and France, Szecesszió in Hungary, Jugendstil in Germany, Secession in Austria, Modernismo in Spain, Arte Nova in Portugal, Stile Liberty or Stile Floreale in Italy, Modern Style in the UK or Tiffany Style in the US. These national movements were united by the desire to break free from the past in order to create a new artistic identity, rooted in the natural world and based on the celebration of medieval craftsmanship as opposed to the mass production made possible by the Industrial Revolution (STERNER 1977).

Although the flowing lines and stylized forms of Art Nouveau appeared in a wide variety of decorative and functional objects - from posters and advertising signs through textile and wallpaper designs, jewels, tiles and other ceramics, furniture, bookplates to stained glass windows (BELANGER GRAFTON 2015), from a tourism point of view, the heritage of the Art Nouveau movement is most evidently represented by architectural masterpieces (KUNDI 2019). Consequently, highlighting the built heritage of Art Nouveau destinations is usually the first step in attracting visitors' attention to all other aspects of this heritage embodied in, for example, graphic art, interior design, jewellery or glass design.

Architecture is simultaneously a site, event and sign (ROSSI 1982): buildings and spaces are may be understood as a set of activities, products and attitudes that complement and complete 
the design and the meaning of specific sites (LASANSKY 2004). Architecture is a key element in the process through which destination marketing organisations and tour operators construct popular perceptions about places (SHAW 2015). Architecture tourism or architourism is a niche cultural tourism product where the visitors' main motivation is seeing buildings and other architectural works (OCKMAN - FRAUSTO 2005), and the destination's architectural assets are a key element in creating a memorable tourist experience. Although architectural tours mainly appeal to purposeful cultural tourists, the built heritage of a destination has a significant influence on the general visitor experience as well, and effective marketing communication using attractive narratives together with a themed landscape approach engaging stakeholders (DE RIDDER - VANNESTE 2020) can generate awareness and interest in the Art Nouveau heritage of the visited destination. Destination marketing organisations play a key role in promoting Art Nouveau heritage as a tourist attraction: while special interest visitors will seek out the niche services created especially for them, most general sightseeing tourists will only explore certain themes during their stay if it appears as a must-see attraction or is clearly articulated in the destination's brand as a slogan or logo (PAPP-VÁRY et al. 2020).

\section{Research methods}

In addition to a literature review focusing on the history and characteristics of the Art Nouveau movement as well as the role of architectural heritage in tourism development, the paper is based on two different empirical methods. On the one hand, with the aim to investigate the current role of Art Nouveau heritage in selected destinations' tourist identity, content analysis of the official tourist websites of the Réseau Art Nouveau Network's (RANN) European member cities was conducted in June 2021 (thus excluding La Habana in Cuba, the Spanish exclave of Melilla in North Africa, as well as Regione Lombardia in Italy, due to its regional character). The Réseau Art Nouveau Network, formed in 1999 as an initial European cooperation network, represents Europe's most important Art Nouveau destinations. Organised as non-profit-making association under Belgian law since 2007, RANN aims to establish active co-operation and an exchange of experiences among the participants actively involved in the study, protection and promotion of Art Nouveau heritage (RANN 2022). As a recognition of the initiative, the Network became a Cultural Route of the Council of Europe in 2014, thus acquiring additional visibility for the continent's Art Nouveau treasures and increased power to raise awareness of this heritage among the general public, cultural and tourism professionals as well as visitors arriving to and travelling within Europe (RANN 2014).

The investigation focused on the inclusion of the Art Nouveau theme in the official destination websites in the following forms: is it (1) embodied in the city's logo, (2) represented in photo(s) on the start page (making further search unnecessary), (3) included in the destination's marketing slogan, and (4) listed among the top sights/attractions of the city?

On the other hand, in order to explore the possibilities of developing a stronger cooperation between the tourism industry and the cultural institutions that represent the Art Nouveau heritage, semi-structured interviews (in person and online) were made with altogether 20 representatives of the tourism sector during May and June 2021. The interviews focused on the current challenges experienced by the tourism industry in successfully developing, promoting and selling Art Nouveau-themed services, as well as their expectations and recommendations for the cultural sector concerning a more efficient cooperation in the future. Experts from the following groups were interviewed as part of the data collection process:

- Incoming and domestic tour operators who are involved in the selection and inclusion of heritage attractions in general and culture-oriented sightseeing tours ( 7 persons) 
- Tour guides (private guides and guides employed by incoming or domestic tour operators or companies organising themed city walks and tours), in co-operation with the Hungarian Tourist Guides' Association (6)

- Hotel managers, concierges and guest relation managers (5)

- Representatives of cultural heritage attractions that have established a successful partnership with the tourism industry (2)

In this paper, since a choice had to be made due to character limits, only the tour guides' perspectives are discussed. Tour guides are among the most influential front-line actors in the tourism industry as navigators of the physical and cultural space (DREW 2011), and they have the possibility to transform destinations into "best places" for their clients by creating narratives based on their local knowledge and experience (AP - WONG 2001). They also have the potential to challenge the touristic representations of their destination by highlighting undervalued resources (IRIMIÁS - MITEV - MICHALKÓ 2021). In urban settings, an important aspect of tour guides' work is to connect discrete sites and emphasise their interrelationship within a cultural landscape framework that acknowledges their interconnected cultural histories and associations (MOYLAN - BROWN - KELLY 2009), thus making their potential contribution invaluable in the promotion of Art Nouveau heritage in tourism destination development.

\section{Research findings}

\subsection{The theme of Art Nouveau in destination marketing}

Since the any collaboration between the tourism industry and the cultural sector takes places within a destination framework (AUBERT et al. 2017), a key success factor of this partnership is the destination image and the messages conveyed by the tourist destination management organisations/convention and visitors bureaus. Many potential visitors gain their first impressions and formulate their travel plans based on the official tourist website of their future destination, while repeat visitors use these sites to search for additional experiences and current events, so the messages conveyed by the DMOs have a significant influence on visitors' perceptions of the place's character and tourist offer (MOLINILLO et al. 2018).

In the case of Alesund, Norway, despite the abundance of natural attractions and activities in the area, the city's cultural identity is unambiguously communicated as "Alesund - The Art Nouveau Town", and the destination's logo reflects its unique architecture. In Aveiro, Portugal, following the Art Nouveau route is listed among the top five don't miss activities. As for Bad Nauheim in Germany, although it welcomes visitors as the City of Health, the fascinating Art Nouveau architecture is mentioned right together with healing mineral springs, green oases and active leisure activities as one of the central components of the personal spa town experience offered by the city. In the case of Brussels in Belgium, Art Nouveau as a general concept is not mentioned directly among the top 20 sights. However, there are two attractions on the list that represent the Art Nouveau style at its height, the Horta Museum located in the former house and studio of Victor Horta, with well-preserved, elegant interior, as well as the new Fin-deSiècle Museum that presents Brussels as the unique artistic crossroads of Europe at the turn of the century and the "capital of Art Nouveau", due to the dynamism of a society that made its mark in every art discipline: literature, painting, opera, music, architecture, photography, and poetry.

Darmstadt in Germany also highlights its "extraordinary Art Nouveau ensemble" on the home page of its official tourist information site, providing detailed information about the Darmstadt Artists' Colony and their creation, the Mathildenhöhe, with a $360^{\circ}$ virtual panorama tour, a 24hour webcam that gives potential visitors a glimpse into the city, and an app that takes visitors 
on a journey through time on Mathildenhöhe with historical views being superimposed over current images. In addition, an online shop offers a wide range of themed souvenirs from microfiber cloths for glasses and coffee mugs through fridge magnets to key rings and mouse pads. Besides the Mathildenhöhe ensemble, the city's many other Art Nouveau elements are also presented, and this heritage is reflected in the badge of the Darmstadt greeters who are willing to show the place to visitors through the locals' eyes.

Art Nouveau is also one of the main themes of the official tourism website of La Chaux-deFonds in Switzerland, in addition to the urban landscape created by the watchmaking industry and protected by UNESCO as a World Heritage site, as well as the architecture of Le Corbusier.

Table 1. The Art Nouveau theme in RANN member cities' tourist websites

\begin{tabular}{|c|c|c|c|c|}
\hline City & Logo & Photo(s) & Slogan & Top attractions \\
\hline Ålesund, Norway & Yes & Yes & $\begin{array}{l}\text { Ålesund }- \text { The Art } \\
\text { Nouveau Town }\end{array}$ & Yes \\
\hline Aveiro, Portugal & No & Yes & No & Yes \\
\hline Bad Nauheim, Germany & No & Yes & No & Yes \\
\hline Barcelona, Spain & No & Yes & No & Yes \\
\hline Brussels, Belgium & No & Yes & $\begin{array}{l}\text { Brussels, the Art Nouveau } \\
\text { capital }\end{array}$ & Yes \\
\hline Budapest, Hungary & No & No & No & No \\
\hline Darmstadt, Germany & No & Yes & No & Yes \\
\hline $\begin{array}{l}\text { La Chaux-de-Fonds, } \\
\text { Switzerland }\end{array}$ & No & No & No & Yes \\
\hline Ljubljana, Slovenia & No & No & No & No \\
\hline Nancy, France & No & Yes & $\begin{array}{l}\text { The French Capital of Art } \\
\text { Nouveau }\end{array}$ & Yes \\
\hline Oradea, Romania & Yes & Yes & No & Yes \\
\hline Riga, Latvia & No & Yes & $\begin{array}{l}\text { The real capital of Art } \\
\text { Nouveau }\end{array}$ & Yes \\
\hline Subotica, Serbia & Yes & Yes & No & Yes \\
\hline Szeged, Hungary & No & Yes & No & Yes \\
\hline Terrassa, Spain & No & Yes & No & Yes \\
\hline Vienna, Austria & No & Yes & No & Yes \\
\hline
\end{tabular}

Source: own collection based on the destinations' official websites

Nancy in France is promoted officially as "the French capital of Art Nouveau", and the city's tourism website offers detailed information on the historical and cultural background on the movement in the city as well as all the visitor attractions and sites that are accessible for tourists. A beautifully illustrated and informative brochure is also available for download (or can be ordered in print) that defines the not-to-be-missed sights, recommends self-guided and guided itineraries and contains all necessary practical information such as maps, opening times and opportunities to save with the Nancy City Pass. In addition, the tourist office also offers tailor- 
made information packages for the press, congress and meeting planners, and groups and tour operators, together with such services as a single contact person to facilitate communication and co-operation, programmes adapted for various disabilities, or guided tours in foreign languages. Although many destination marketing and management organisations offer similar services, the website of Destination Nancy is particularly well-structured, transparent and easy to use.

On the official tourism website of Oradea, Romania, \#ArtNouveau is the first hashtag that appears, and the message that "Oradea is much more than Art Nouveau" actually highlights the significance of this heritage in the city's tourist identity. In addition, various examples of Art Nouveau architecture are mentioned on the list of the city's top 10 must see sites, such as the Black Eagle Palace, one of the most representative Art Nouveau monuments in Transylvania and an emblematic building of Oradea.

Riga in Latvia positions itself as "the real capital of Art Nouveau" in Europe, due to the fact that this architectural style makes up around one-third of all the buildings of the city centre, and Art Nouveau is the basis on which Riga's historical centre was listed as a UNESCO World Heritage Site in 1997. All the promotional materials available on the city's official tourism website emphasise this heritage and contribute to developing a strong destination identity that also influences visitors' image of the city and has an impact on their demand patterns and activities.

Art Nouveau architecture is also highlighted on the official tourism website of Subotica, Serbia, with detailed descriptions and rich visual illustration of the city's landmark buildings representing Vienna Secession and Hungarian Art Nouveau style. Similarly, architectural heritage is featured among the most important sights in Szeged, Hungary, with special emphasis on the city's Art Nouveau buildings that are located all around the city in a mosaic pattern. Subotica and Szeged - together with Serbian Palić and Senta - are connected via the theme of Art Nouveau, both in the artistic-historical sense and through a previous Hungary-Serbia IPA Cross-border Cooperation Programme that aimed to develop cultural and tourism co-operation among the destinations. Although current visitor numbers indicate a relatively low market share of Hungarian tourists in Northern Serbia, the area has major development potential, and one of the key products might be cultural tourism based on heritage resources associated with Hungarian identity (TÖZSÉR 2019).

The Catalan city of Terrassa has built its destination image on the concept of industrial Modernism, since the heritage of Art Nouveau is strongly connected to the development of the textile industry in the $19^{\text {th }}$ century, and is reflected mainly in industrial architecture. The city's tourist office, itself located in the Masia Freixa, a Gaudí-inspired building built by architect Lluís Muncunill, offers both guided and self-guided tours to discover "the most complete Modernist complex in the world applied to industrial architecture", with attractions including former private residences and industrial buildings converted into museums and exhibition halls.

The official tourism websites of Barcelona and Vienna, the two most visited urban destinations in the Réseau Art Nouveau Network, aim to transmit more complex messages, in order to avoid the negative consequences of overtourism such as the concentration of visitors around certain honeypot attractions (TÖZSÉR 2021). In Barcelona, the website suggests a list of interesting districts, themed routes and day itineraries that all serve the same purpose: demonstrating the richness of the city's cultural and tourist offer and encouraging visitors to venture off the beaten path. Among the themed routes suggested in Barcelona, the Art Nouveau heritage is featured in several, e.g. the Modernista Route, the Gaudí Route, the Josep Puig i Cadafalch Route or the Lluís Domènech i Montaner Route, and the "jewels of Catalan Art Nouveau, modernism", is mentioned as the first item on the destination's must see list. In Vienna, the start page of the 
city's tourist website focuses mainly on seasonal activities and events, but „golden Art Nouveau" is mentioned among the first experiences recommended for sightseers, and there is a comprehensive list of Art Nouveau heritage sites including, among others, the Secession building, Otto Wagner's Stadtbahn Pavilions, the art collections of the Belvedere Palace, the MAK - Museum of Applied Arts, and a great variety of themed walks and tours exploring the artistic masterpieces and architecture landmarks of the city.

In contrast with the majority of RANN member cities, Budapest in Hungary does not promote actively its Art Nouveau heritage. It is not listed among the top 10 attractions illustrated with photos, and although it is briefly mentioned as an alternative top sight in a more detailed written description of the city as "On another day, the Top 10 of Budapest could be a list of another ten sights of a similar level - it could just as well include the Applied Arts museum, which is part of our Secessionist heritage", visitors - especially first time visitors who are not familiar with the destination's tourist offer - are typically influenced by visual elements, so based on this message, they are much less likely to associate Budapest with Art Nouveau than the other member cities of the Network. In addition, the fact that the city's Art Nouveau heritage is not highlighted by the official brand agency has an unfavourable impact on the inclusion of this heritage in tour operators' and tour guides' programmes: typical sightseeing tours are based on attractions that are strongly associated with the given destination's image, i.e. must see sites that most visitors wish to see. Tourism companies that wish to differentiate their own offer need to find a precarious balance between the too popular and the completely unknown, and are more willing to move off the beaten path if the risks of doing so are limited, if there is a measurable demand on behalf of the guests (or the partner agencies) for a certain theme. Consequently, the first steps in establishing a more efficient partnership between the cultural sector representing Art Nouveau and the tourism industry in Budapest should be taken on destination management level. Since the city actually does have an impressive range of Art Nouveau sites that are truly popular among tourists, from the spectacular Gellért Baths through the impressive Museum of Applied Arts to the beautifully restored Gresham Palace - Four Seasons Hotel, a well-designed communication campaign could relatively easily reinforce Budapest's Art Nouveau identity.

The situation is slightly similar in the official destination marketing communication of Ljubljana, Slovenia: the top 10 attractions' list does not immediately highlight the city's Art Nouveau heritage, only a deeper and more culture-oriented search will take the visitors to detailed information on the unique aspects of Slovenian Art Nouveau. However, one of the must see sights, the Dragon Bridge is presented as an extraordinary piece of technical heritage and a "superb example of Art Nouveau architecture", and its informative description successfully introduces the theme to the destination's visitors.

\subsection{Key factors in successful co-operation with tour guides in the promotion of Art Nouveau heritage}

The involvement of tour guides in cultural tourism is particularly important, since both purposeful and sightseeing cultural tourists (MCKERCHER 2002) - i.e. the key market segments in this field - have a higher than average propensity to join guided tours during their trip. However, while sightseeing tourists are generally satisfied with visiting the top sights of a place (which highlights again the significance of featuring Art Nouveau as a must see theme in destination marketing), purposeful cultural tourists travelling alone or in small groups are typically open to new and unusual experiences, so their programmes may considerably be influenced by local tour guides' creativity, suggestions and ideas.

Individual guides working in a destination select their own themes and create their own itineraries, while those with a tour operator contract have a major influence on the types and exact content of sightseeing tours offered to international partner agencies and individual 
tourists. The main precondition of incorporating the theme of Art Nouveau in these programmes is sufficient familiarity with the destination's Art Nouveau heritage, its history, characteristics, key figures, unique features of the local style in international comparison, as well as the range of visitor attractions and the experiences and services provided by them.

In comparison with tour operators, while guides also need to be familiar with the practical details of visiting Art Nouveau attractions (location, access, prices, opening hours, services), they need a much deeper background knowledge of the movement itself and its manifestation in architecture, interior design, jewellery and glass design, graphic arts etc., with special emphasis on the given destination. They also need to be familiar with the artists, their life and work, style, inspirations, and influences, as well as their personal and artistic heritage. Besides all the factual information however, tour guides need memorable stories that can pique visitors' interests, and have to be able to identify highlights for visits of various lengths of time (from 30 minutes to several days).

If a destination's Art Nouveau heritage is emphasised in tourism marketing, it usually influences visitors' interest in this heritage and leads to increasing demand for Art Nouveau experiences (themed tours or walks, exhibitions, interactive workshops or other activities). This will motivate first specialised and niche tour guides (and tour operators) to include this theme in their tours, then, as Art Nouveau becomes a must see attraction, as it happened with Gaudí's architecture in Barcelona, it will also be featured in every sightseeing tour, guide book, tourist website, and social media platform.

However, as we have seen earlier, Art Nouveau is not an equally significant element in the destination identities of all RANN member cities. In those cities where this theme is not an integral component of the tourist destination image, guides have to use their creativity to incorporate Art Nouveau in their offer (e.g. in Budapest a good starting point for making guests familiar with this style could be the picturesque Gellért Baths, since spas are promoted among the city's top experiences and are popular among tourists). In addition, they also need the cultural sector's assistance and collaboration in their efforts to make the place's Art Nouveau heritage visible and attractive for visitors.

A (printed or interactive) city map depicting the prominent Art Nouveau buildings and other attractions can help guides to present the value and significance of this heritage to visitors. It is important though not to provide too much information: for example, the otherwise very informative and impressive Art Nouveau Danube digital repository is not ideal from a tour guide's perspective as it is rather time-consuming to identify the must show highlights among the hundreds of digital objects and artefacts.

Setting up multilingual information boards at the key Art Nouveau attractions of a destination, with the description of the site's significance, a few photos, and a map indicating the locations of all the other Art Nouveau sights would also increase the visibility of this heritage, raise visitors' curiosity, and encourage guides to include this theme in their tours, similarly to creating experiences optimised for social media.

Since knowledge is the most important value that guides add to a visit, they need to thoroughly prepare for each tour. Visitor attractions can help this preparation by providing free admission for licensed guides (not only in the company of clients, but also alone), and by putting together a guide kit that

- contains information on the history and most important features of the attraction (preferably not only technical information, but also personal stories),

- provides lists of highlights for short/medium/long visits, 
- $\quad$ suggest different themes and itineraries within the attraction, and

- summarizes practical details such as opening hours, booking process for groups, access with disability, prices and commission, parking, dining and shopping facilities etc.

As half-day and full-day sightseeing tours need to cover many sights, the time available for each site is very limited. However, even a brief visit can give a glimpse of an Art Nouveau attraction's value to visitors and may motivate them to return later, either on their own or as participants of a specialised cultural tour. Based on a special agreement between guides and attractions, the clients of tour guides could be offered an incentive to return, e.g. discounted admission for their second visit or a drink voucher if the attraction has a café or a $10 \%$ off voucher in the gift shop or at least a printed brochure promoting the attraction. This way, the guide would be in the position to offer extra value to their clients which would improve their competitiveness in the market of sightseeing tours, the guest would feel more motivated to return, and the attraction would benefit from higher visitor numbers.

An increasingly popular solution to establish a partnership between tour guides and cultural institutions is the organisation of training courses for licensed guides, often in co-operation with the national guides' association. These courses include guided visits to the attraction in order to demonstrate the institution's best practices, and provide materials for self-study. At the end, only those external guides who successfully pass the attraction's exam are authorised to conduct tours for their own clients (this exclusive right is usually demonstrated by a special sticker or hologram on their tour guide badge/license). Participation in such training courses has a positive impact on guides' interest in and willingness to include the attraction in their own itineraries: their position in the competitive market of sightseeing tours is improved by their ability to offer their guests a special service and, more importantly, after having passed the exam they feel more empowered and better prepared to present a certain theme.

\section{Conclusions}

Art Nouveau is a unique asset in European - and Hungarian - cultural heritage: it is a globally recognised style of fine art, architecture and applied art that can have significant impact on a destination's identity and competiveness, at least if managed and communicated properly. As the brief analysis of the RANN members tourist websites illustrated, even those cities that acknowledge and appreciate their Art Nouveau heritage enough to join the most prestigious international network in this field do not necessarily take full advantage of the tourist potential of these resources. This might be explained, at least partly, by the lack or low level of cooperation between the art and heritage sector and the tourism industry: the ARTNOUVEAU2 project aims to stimulate collaboration in this field. The situation is particularly controversial in Budapest where, on the one hand, examples of Ödön Lechner's distinctive architecture were included on the country's tentative World Heritage list in 2008, suggesting that they are considered to be of outstanding value for humanity, while on the other hand, Art Nouveau as a theme is not highlighted as a unique brand element in destination marketing, and the offer of related tourism services is also rather limited.

The best practices in this field, predominantly applied in cities where Art Nouveau is perceived as a central component of the destination's identity, illustrate the development potential of this resource. The aesthetic ideal embodied by the Art Nouveau movement, the Gesamtkunstwerk or synthesis of the arts, resulted in unified architecture, interior design and art that aimed to inspire, uplift, and produce a creative harmony. These objectives are also familiar to a wide and diverse range of tourism service providers, from the luxury accommodation sector to cultural and creative tourist attractions, from spa and wellness retreats to destination marketing organisations. An Art Nouveau-themed milieu, due to its decorative style and flowing patterns based on natural motives such as flowers, butterflies, dragonflies, vines or birds, generally gives 
a sensation of lightness and harmony, and has the capacity to transform good places into "best places", both from an individual experience perspective and in the commercial sense of the concept.

Tour guides can make an important difference in visitors' perceptions of a destination, from the anticipation phase to the actual experience. Improving communication and co-operation between tour guides and the cultural sector representing Art Nouveau heritage helps promote these resources among wider visitors segments, can assist the guides in developing alternative tours and narratives, and can contribute to creating more distinctive and more competitive destination identities.

\section{Acknowledgements}

This study was carried out within the framework of the ARTNOUVEAU2 "Strengthening the cultural identity of the Danube region by building on common heritage of ART NOUVEAU" project which is co-funded by European Union funds (ERDF, IPA II). The Hungarian partner's participation is co-funded by the Hungarian Government.

This study was supported by OTKA (134877).

The author would like to thank Dr. Viktória Kundi and Dr. Tamás Régi who provided insight and expertise that greatly assisted the research.

\section{References}

AP, J. - WONG, K. K. F. (2001): Case study on tour guiding: Professionalism, issues and problems. Tourism Management 22(5): pp. 551-563.

AUBERT, A. - BARCZA, A. - GONDA, T. - HORVÁTH, Z. - PÁLFI, A. (2017): Paradigmaváltás(ok) a magyarországi turisztikai desztinációk fejlesztésében és menedzselésében. Turizmus Bulletin 17(1-2): pp. 15-25.

BELANGER GRAFTON, C. (2015): Art Nouveau. The Essential Reference. Dover Publications, Inc., Mineola, NY.

DE RIDDER, K. - VANNESTE, D. (2020): Tourism development through landscape theming: Exploring Art Nouveau experiences in Brussels. Journal of Tourism, Heritage \& Services Marketing 6(2): pp. 45-54.

DREW, E. M. (2011): Strategies for antiracist representation: ethnic tourism guides in Chicago. Journal of Tourism and Cultural Change 9(2): pp. 55-69.

\section{EUROPEAN COMMISSION (2017): Cultural tourism.} https://ec.europa.eu/growth/sectors/tourism/offer/cultural_en (downloaded 21.06.2021)

IRIMIÁS, A. - MITEV, A. - MICHALKÓ, G. (2021): The multidimensional realities of mediatized places: the transformative role of tour guides. Journal of Tourism and Cultural Change 19(6): pp. 739-753.

KUNDI, V. (2019): A turisztikailag legfontosabb szecessziós épületek Budapest belvárosában. Vállalkozói Értesitö - Vendéglátás és Turizmus 11: pp. 11-14.

LASANSKY, D. M. (2004): Introduction. In: Lasansky, D. M. - McLaren, B. (Eds.): Architecture and Tourism. Perception, Performance and Place. Berg, Oxford. pp. 1-12.

LENNING, H. F. (1951): The Art Nouveau. Springer-Science+Business Media, B.V., Dordrecht. 
MCKERCHER, B. (2002): Towards a classification of cultural tourists. International Journal of Tourism Research 4(1): pp. 29-38.

MICHALKÓ, G. - FAZEKAS, I. (2016): Jó helyek, jó gondolatok, jó cselekedetek: a turisztikai desztinációk szerepe az utazók inspirálásában. In: Kókai, S. (szerk.): A változó világ XXI. századi kihívásai. Nyíregyházi Egyetem Turizmus és Földrajztudományi Intézete, Nyíregyháza. pp. 409-420.

MILLER, J. - BACE, J. - RAGO, D. - PERRAULT, S. (2004): Art Nouveau. DK Collector's Guides. Dorling Kindersley Limited, London.

MOLINILLO, S. - LIÉBANA-CABANILLAS, F. - ANAYA-SÁNCHEZ, R. - BUHALIS, D. (2018): DMO online platforms: Image and intention to visit. Tourism Management 65: pp. 116130.

MOYLAN, E. - BROWN, S. - KELLY, C. (2009): Toward a cultural landscape atlas: Representing all the landscape as cultural. International Journal of Heritage Studies 15(5): pp. 447-466.

NETHERLANDS MUSEUMS ASSOCIATION (2011): The Social Significance of Museums. DSP-groep on behalf of the Netherlands Museums Association, Amsterdam.

OCKMAN, J. - FRAUSTO, S. (Eds.) (2005): Architourism: Authentic, Escapist, Exotic, Spectacular. Prestel, Munich.

OECD (2014): Tourism and the Creative Economy. OECD Studies on Tourism, OECD Publishing, Paris.

OOI, C-S. (2007): Creative Industries and Tourism in Singapore. In: Richards, G. - Wilson, J. (Eds.): Tourism, Creativity and Development. Routledge, London. pp. 240-251.

PAPP-VÁRY, Á. - WOLF, D. - FARKAS, M. - SZOLNOKI, Sz. (2020): Turisztikai szlogenés logóhasználat az európai fövárosok esetében - Milyen szavakkal hívogatnak, milyen jelképekkel csalogatnak? Turisztikai és Vidékfejlesztési Tanulmányok 5(2): pp. 15-41.

RANN (2022): About us. https://www.artnouveau-net.eu/about-us/ (downloaded on 10.01.2022)

RANN (2014): The Réseau Art Nouveau Network now Cultural Route of the Council of Europe! https://www.artnouveau-net.eu/the-reseau-art-nouveau-network-now-cultural-routeof-the-council-of-europe/ (downloaded on 11.01.2022.)

RÁTZ, T. (2017): 'Be global, go local' - innovation and creativity in the development of alternative guiding services in Budapest. Journal of Tourism and Cultural Change 15(5): pp. 476-489.

RICHARDS, G. (2021): Rethinking Cultural Tourism. Edward Elgar Publishing, Inc., Cheltenham.

ROSSI, A. (1982): Architecture of the City. MIT Press, Cambridge MA.

SCERRI, M. - EDWARDS, D. - FOLEY, C. (2018): Design, architecture and the value to tourism. Tourism Economics 25(5): pp. 695-710.

SHAW, G. B. C. (2015): Tourism by design: signature architecture and tourism. Tourism Review International 19(4): pp. 235-241.

STERNER, G. (1977): Art Nouveau. An Art of Transition - From Individualism to Mass Society. Third edition. DuMont Publishers, Cologne. 
TÖZSÉR, A. (2021): Challenges for sustainable tourism using Barcelona as a case study. Turisztikai és Vidékfejlesztési Tanulmányok 6(2): pp. 117-127.

TŐZSÉR, A. (2019): A Délvidék/Vajdaság turisztikai kínálata és kereslete. Turisztikai és Vidékfejlesztési Tanulmányok 4(3): pp. 36-51.

UNWTO (2018): Tourism and Culture Synergies. UN World Tourism Organization, Madrid.

WTO (2001): Cultural Heritage and Tourism Development. WTO, Madrid.

WTO (1985): State's Role in Protecting and Promoting Culture as a Factor of Tourism Development. WTO, Madrid.

\section{Tourism websites of RANN member cities}

szegedtourism.hu (accessed on 13 June 2021)

visit.brussels (accessed on 8 June 2021)

visitaterrassa.cat (accessed on 13 June 2021)

visitsubotica.rs (accessed on 13 June 2021)

www.bad-nauheim.de (accessed on 3 June 2021)

www.barcelonaturisme.com (accessed on 8 June 2021)

www.budapestinfo.hu (accessed on 8 June 2021)

www.centerofportugal.com/destination/aveiro (accessed on 3 June 2021)

www.chaux-de-fonds.ch (accessed on 12 June 2021)

www.darmstadt-tourismus.de (accessed on 12 June 2021)

www.liveriga.com (accessed on 13 June 2021)

www.nancy-tourisme.fr (accessed on 12 June 2021)

www.visitalesund.com (accessed on 3 June 2021)

www.visitljubljana.com (accessed on 12 June 2021)

www.visitoradea.com (accessed on 12 June 2021)

www.wien.info (accessed on 8 June 2021) 